\title{
Mangroves Assessment and Diversity in Coastal Area of Barangay Cagdianao, Claver, Surigao Del Norte, Philippines
}

\author{
Alvin B Goloran ${ }^{1 *}$, Meljan T Demetillo ${ }^{2}$ and Glenn L Betco ${ }^{3}$ \\ ${ }^{1}$ Pigdaulan National High School, Philippines \\ ${ }^{2}$ Department of Biology, Caraga State University, Philippines
}

${ }^{3}$ City Environment and Natural Resources, Philippines

Submission: October 23, 2020; Published: November 05, 2020

*Corresponding author: Alvin B Goloran, Pigdaulan National High School, Butuan City, Philippines

\section{Abstract}

According to the National Mapping and Resources Information Authority (NMRIA), Philippines has about 7,641 islands with 3 major islands, Luzon, Visayas, and Mindanao and about 300,000 square kilometers area with vast areas of mangrove ecosystem along shoreline. Government policies, which dictated development in both the uplands and coastal areas, have been based mainly on abundant available resources without due consideration for sustainability. The study was conducted for the purpose to identify mangroves diversity and assessment in barangay Cagdianao particularly near the mining area for the purpose of rehabilitation and conservation. Random sampling was used and with a total number of six stations having three (3) 10 x 10 meters' quadrat. Results revealed a total of 9 species of mangroves within the areas of Barangay Cagdianao. Family Combretaceae and Rhizoporaceae dominated the area. Lumnitzera littorea and Lumnitzera racemosa dominated in all sampling stations. Eight species were recorded to be Least Concern and one species was considered Vulnerable (Avicennia rumphiana). Among the species, Lumnitzera littorea was the most dominant speciesfollowed by mangrove fern Acrostichum speciosum. Based on the results, mangrove areas of the Brgy. Cagdianao, Claver, Surgao del Norte falls under the category of very low biodiversity. Even if the area has low biodiversity, results revealed that the mangroves in Cagdianao experienced minimal disturbances from any anthropogenic activity.

Keywords: Mangroves; Diversity; Assessment; Species

\section{Introduction}

\section{Mangroves}

In the tropical coastline, mangroves and seagrass beds are prominent features [1] with great ecological and economic value [2]. Mangroves are one of the most exceptional floras group in the world and grow in the coastlines of tropical and sub-tropical countries and are well adapted to extreme conditions such as high salinity and temperature [3]. The remaining mangrove areas of the world in 2000 was 53,190 square miles $(137,760$ $\mathrm{km}^{2}$ ) spanning 118 countries and territories all throughout [4]. Mangroves provide many and useful human products, resources and ecological services such as wood-fire, ethnomedicinal, clean air and typhoon/flood protection. Moreover, it helps maintain ecological balance in an ecosystem. According to mangroves maintain coastal water quality and form a barrier for coastal protection from wave storm and flood damage [5]. Mangroves very important area in an ecosystem. Provides food to many fishes, invertebrates and birds and provide protection to any coastal catastrophic events [6,7].
The Philippines has very rich biodiversity in terms of number and percentage and regarded as one of 17 mega biodiversity countries due to its geographical isolation [8]. The country holds $50 \%$ of the world's mangrove species [9] from 65 known species of mangroves in the world [3]. One for the top 15 countries in the world [10].

The rehabilitation, conservation, and protection of mangrove forests along coastal areas of the Philippines should be the collaborative effort between the Local Government Units, Department of Environment and Natural Resources (DENR) as main agency for environment in the Philippines and all stakeholders to make sustainable long term plans. The study of Goloran et al. [11] in selected part in Caraga Region particularly in Agusan del Norte showed that the mangrove community present in mentioned area were under ecological threat due to many identified anthropogenic factors.

To address some issues on mangrove degradation and habitat loss, this study purposely conducted to mangrove assessment, 
diversity, composition and ecological status in barangay Cagdianao, Claver, Surigao del Norte, Caraga considering that the mangroves forest in the area are near the large scale nickel mining sites.

\section{Materials and Methods}

\section{Study area}

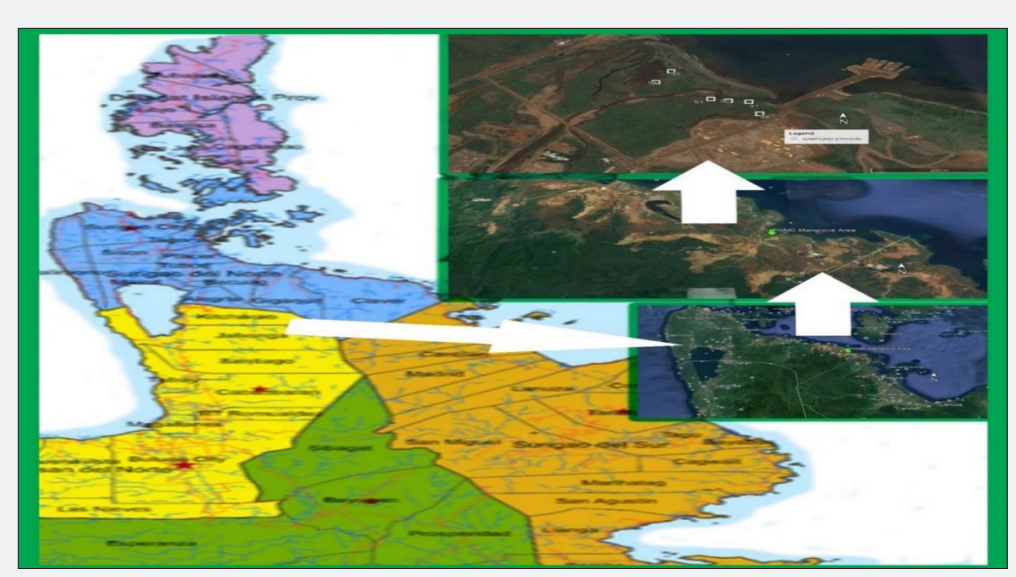

Figure 1: Map of Brgy. Cagdianao, Claver, Surigao del Norte, Caraga..

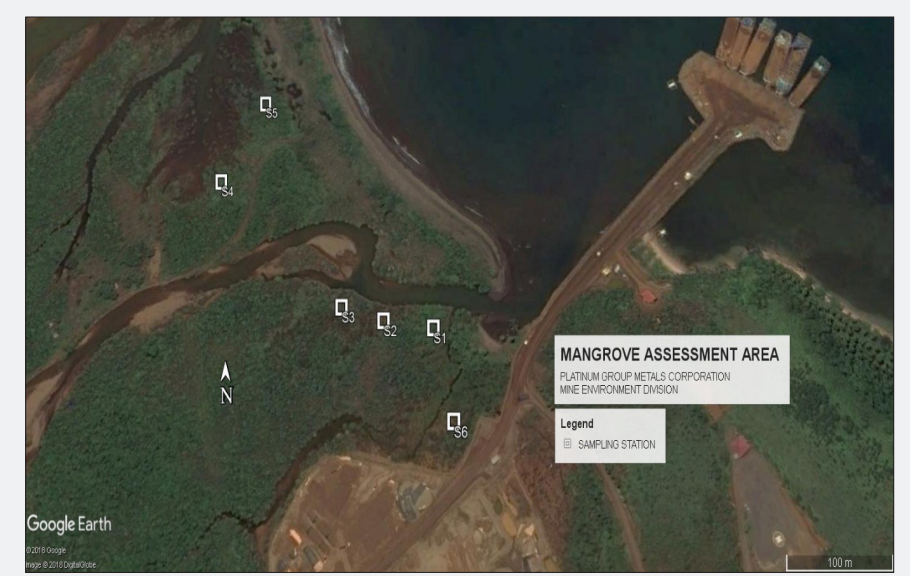

Figure 2: Aerial view of all sampling sites of mangrove assessment and the established permanent sites using GoogleEarth (image copyright 2018 Digital Globe).

The study area was within the mangrove and rehabilitation areas near Platinum Group Metals Corporation (PGMC) located at Brgy. Cagdianao, Claver, Surigao Del Norte (Figure 1). It is one of large scale mining areas in the province of Surigao del Norte specifically located at $9^{\circ} 29^{\prime} 42.13^{\prime \prime} \mathrm{N}$ and $125^{\circ} 52^{\prime} 18.10^{\prime \prime} \mathrm{E}$. There were 6 sampling stations established with three $10 \times 10 \mathrm{~m}$ quadrats per site (Figure 2).

\section{Transect line and sampling station establishment}

Six permanent sampling stations were established within the mangrove areas. Each station had a transect line ranges from 100 to 200 meters perpendicular to the shoreline. Every station and transect line (3) three $10 \times 10$ plots were established randomly with a distance ranges 15-30 meters and depend on the structure of mangrove community $[11,12]$. Random sampling allows the researcher to easily determine the composition of mangroves and its type of species. Because individuals are rarely evenly distributed within an area, it is important to sample randomly to ensure that we get a true representation of the population. Mangrove species inside the plot were identified and counted including diameter breast height (dbh), canopy cover (cc), density and height were measured as described by English et al. [13]. Three (3) 1x1m subplots were established in counting of individuals for seedlings and saplings (planted seedlings not included in the counting). Each mangrove within the plots was characterized as seedling, sapling and mature tree based on the definition of Deguit et al. [14]. 


\section{Mangrove identification}

The mangroves within sub-plots and plots were identified and classified taxonomically using the field guide manual to Philippines Mangroves by Primavera et al. [10].

\section{Diversity indices and scale}

Using Paleontological Statistical Software Package (PAST) developed by Hammer et al. [15], Shannon-Weiner diversity index, species richness, relative abundance, and evenness were calculated. PAST software is the free-ware widely used by many researchers for flora and fauna inventory including mangroves.

\section{Mangrove species ecological status, occurrences and population trends}

Mangrove species status, occurrences, and trends are classified and identified using the recorded online tool, the International Union for Conservation of Nature (IUCN) red list and the DENR Administrative Order No. 11 series 2017 known as the Updated List of Threatened Philippine Plants and their Categories [16].

\section{Results and Discussion}

\section{Species composition and ecological status}

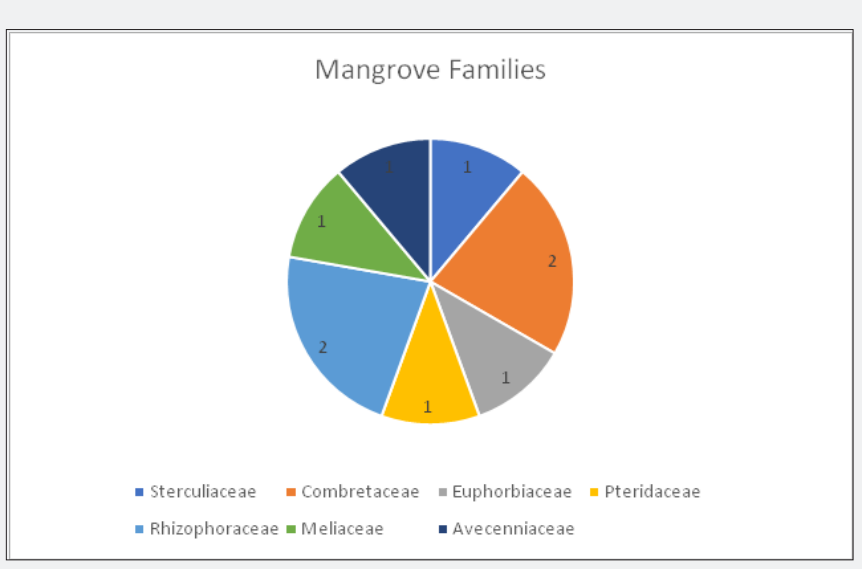

Figure 3: Mangrove families present in Brgy. Cagdianao.

A total of 9 species of mangroves were identified under 7 families within the mangrove areas of Barangay Cagnianao, Claver Surigao del Norte. Family Combretaceae and Rhizoporaceae dominated the area followed by Pteridaceae, Euphorbiaceae, Sterculiaceae, Avecenniaceae, and Meliaceae (Figure 3).

Among the families, Combretaceae dominated the whole area in terms of population and density. Among species Lumnitzera littorea and Lumnitzera racemosa were the most abundant in all sampling stations. For conservation status, 8 species were recorded to be Least Concern (LC) while 1 species considered
Vulnerable (V), based in International Union for Conservation of Nature (IUCN) red list (Table 1 \& 2) Based on IUCN, all species of mangroves identified in all sampling sites were considered widespread throughout the countries and other continents outside Philippines. This is also related to studies conducted by Demetillo et al. [17], that some species in Caraga Region were threatened and endangered. Though all species are considered widespread and only was vulnerable, eight (8) species out of 9 are decreasing in population trends as recognized by the IUCN Red List.

Table 1: Species composition.

\begin{tabular}{|c|c|c|c|}
\hline No. & Family & Species & Avicennia rumphiana \\
\hline 1 & Avecenniaceae & Lumnitzera littorea & Kabaw/Tabaw \\
\hline 2 & Combretaceae & Lumnitzera racemosa & Excoecaria agallocha \\
\hline 3 & Combretaceae & Xylocarpus granatum & Tabaw \\
\hline 4 & Euphorbiaceae & Acrostichum speciosum & Bruguiera sexangula \\
\hline 5 & Pteridaceae & Rhizophora apiculata \\
\hline 7 & Rhizophoraceae & Heritiera littoralis \\
\hline 9
\end{tabular}


International Journal of Environmental Sciences \& Natural Resources

Table 2: Mangrove Ecological Status, Occurrences and Population Trends.

\begin{tabular}{|c|c|c|c|}
\hline Acrostichum Speciosum & Least Concern & Widespread & Stable \\
\hline Avicennia rumphiana & Vulnerable & Widespread & Decreasing \\
\hline Bruguiera sexangula & Least Concern & Widespread & Decreasing \\
\hline Excoecaria agallocha & Least Concern & Widespread & Decreasing \\
\hline Heritiera littoralis & Least Concern & Widespread & Decreasing \\
\hline Lumnitzera littorea & Least Concern & Widespread & Decreasing \\
\hline Lumnitzera racemosa & Least Concern & Widespread & Decreasing \\
\hline Rhizophora apiculata & Least Concern & Widespread & Didespread \\
\hline Xylocarpus granatum & Least Concern & & Decreasing \\
\hline
\end{tabular}

\section{Relative abundance}

Figure $4 \& 5$ shows the relative percent abundance of all mangrove species identified in all sampling stations. Among the species, Lumnitzera littorea obtained the highest percentage value in terms of abundance (30.89\%), followed by mangrove fern Acrostichum speciosum (23.94\%) and Lumnitzera racemosa (17.55 \%). L. littorea is distributed in tropical Asia and Australia.
In China, it is an endangered species confined to restricted regions of Hainan Province [18]. Tomlinson et al. [19] stated that L. littorea is pollinated predominantly by honey-eaters such as the graceful honeyeater (Meliphaga gracilis (Gould), various sunbirds, bees and wasps. This could be a good indicator that there are still many faunal species found and relied on L. littorea within the mangrove area of Brgy Cagdianao.

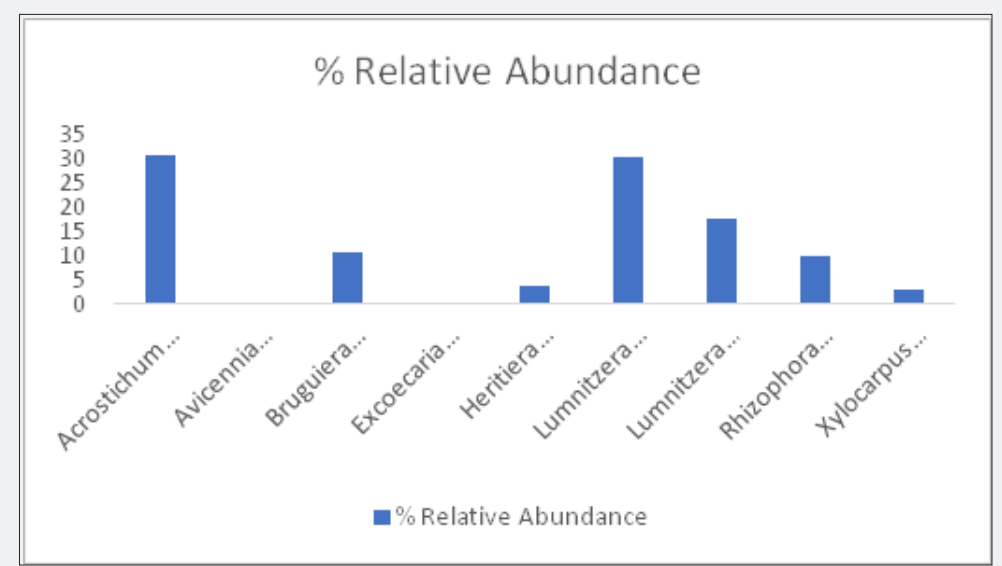

Figure 4: Relative Abundance of mangroves found along Brgy. Cagdianao, Claver, Agusan del Norte.

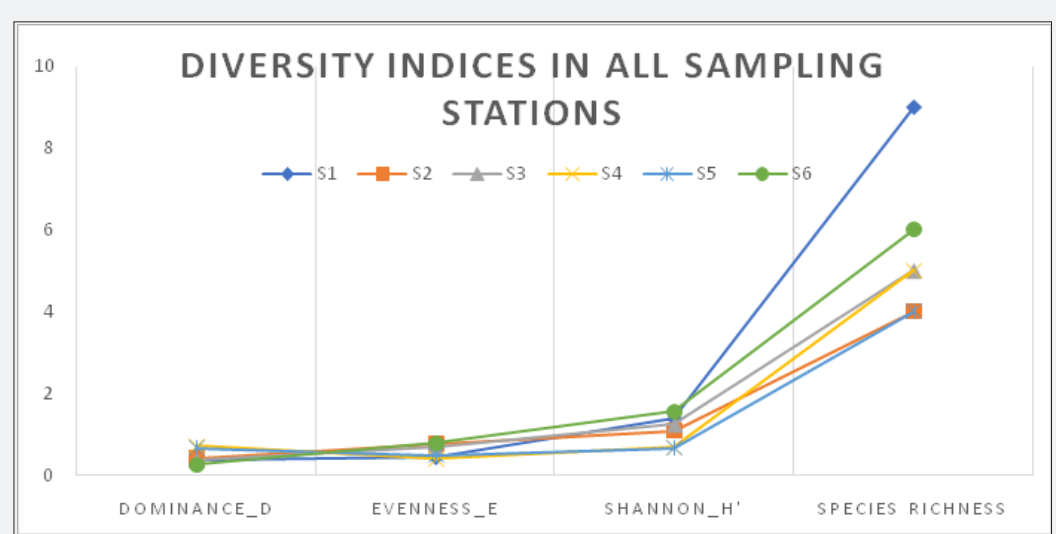

Figure 5: Diversity Indices in all 6 sampling sites in mangrove area of Brgy. Cagdianao, Claver, Surigao del Norte, Philippines. 


\section{Species richness}

In 6 sampling stations, station one (S1) obtained the highest value in terms of individuals and species richness with a total of 162 individuals and 9 species respectively. Station 6 (S6) got high diversity results with 1.542 and Station 4 (S4) got the Dominance value of 0.7022 (Figure 5).

\section{Canopy Cover}

Canopy cover plays an important role in the amount of sunlight that penetrates the forest floor. Scientists classify forest canopies as open $(10-39 \%$ of the sky is obstructed by tree canopies), moderately closed $(40-69 \%$ of the sky is obstructed by tree canopies) or closed (70-100\% of the sky is obstructed by tree canopies). Densiometer is used to measure this light however because of resources, many researchers used the alternative way in measuring canopy cover and this is to position at the center of every quadrat. In all 6 stations, station 1 (S1) (73.33\%) was estimated denser compared to the rest of the stations (Figure 6). The estimation affirmed that station 1 (S1) has a high number of individuals of mangrove trees. It was also recorded that station 1 obtained the high number of species density. The total average canopy cover within the mangrove area of PGMC has a total value of 43.88 or $43 \%$ which is interpreted as Moderately Closed (MC) canopy per square meter $\left(\mathrm{m}^{2}\right)$. With these results, this can be interpreted that the area still has an intact mangrove population density but need close monitoring and be provided with a systematic rehabilitation plan for more improvements.

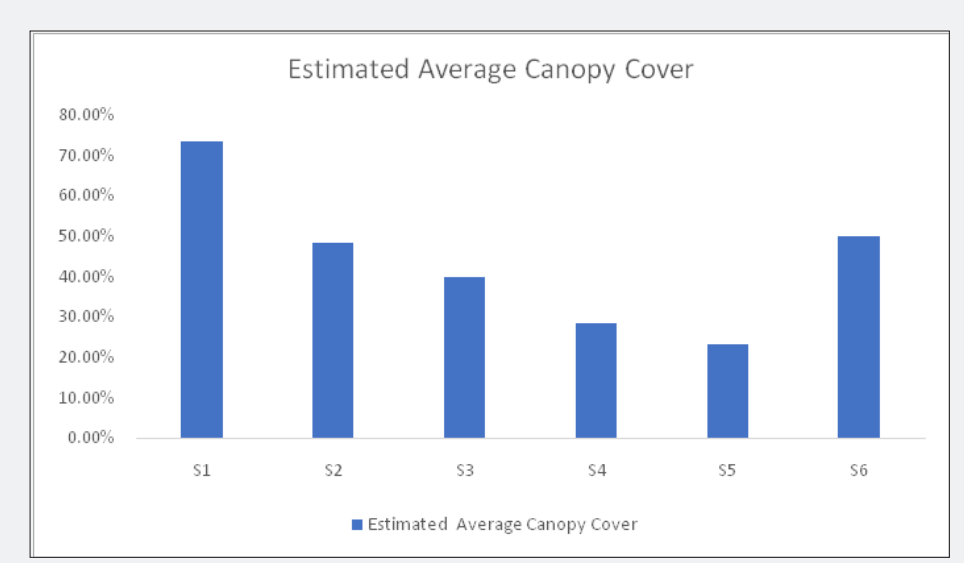

Figure 6: Estimated canopy cover in all sampling stations within the mangrove area of Brgy. Cagdianao, Claver, Surigao del Norte.

\section{Regeneration and estimated average height}

The regeneration count for sapling and seedlings was calculated using the formula described in the methodology.
Planted seedlings by the personnel were not included and only natural seedlings/saplings are recorded below the mangrove tree species. Figure 7 shows the regeneration per square meter $\left(\mathrm{m}^{2}\right)$ and estimated average height of mangrove trees.

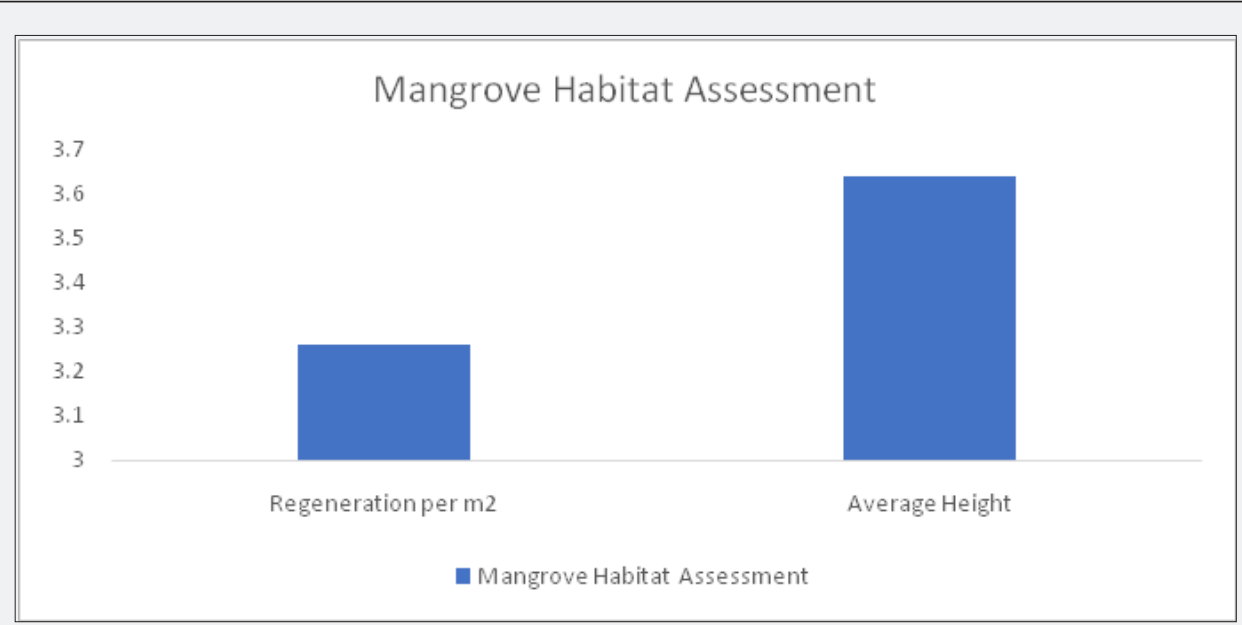

Figure 7: Mangrove habitat assessment within mangrove area of PGMC, Brgy. Cagdianao, Claver, Surigao del Norte. 
Based on the classification given by Deguit et al. [14], the regeneration (3 individuals per $\mathrm{m}^{2}$ was considered excellent and moderate category for average height (3.64 meters) of mangroves. Excellent means undisturbed to any negligible disturbances and fair means moderate disturbances. Though mangrove habitat assessment provides good results within mangrove areas of Cagdianao there were still minimal disturbances observed during the actual sampling and this was illegal cutting of mangrove trees (Figure 8) used as firewoods by locals and illegal hunting of faunal species. Illegal hunting of different faunal species is a clear violation of RA 9147 otherwise known as "Wildlife Conservation Act". If this will continue, it will affect the whole mangrove community because faunal species found within the mangrove areas are the main pollinators and the natural planters of this type of ecosystem. Conservation, protection, and education should strictly observe.

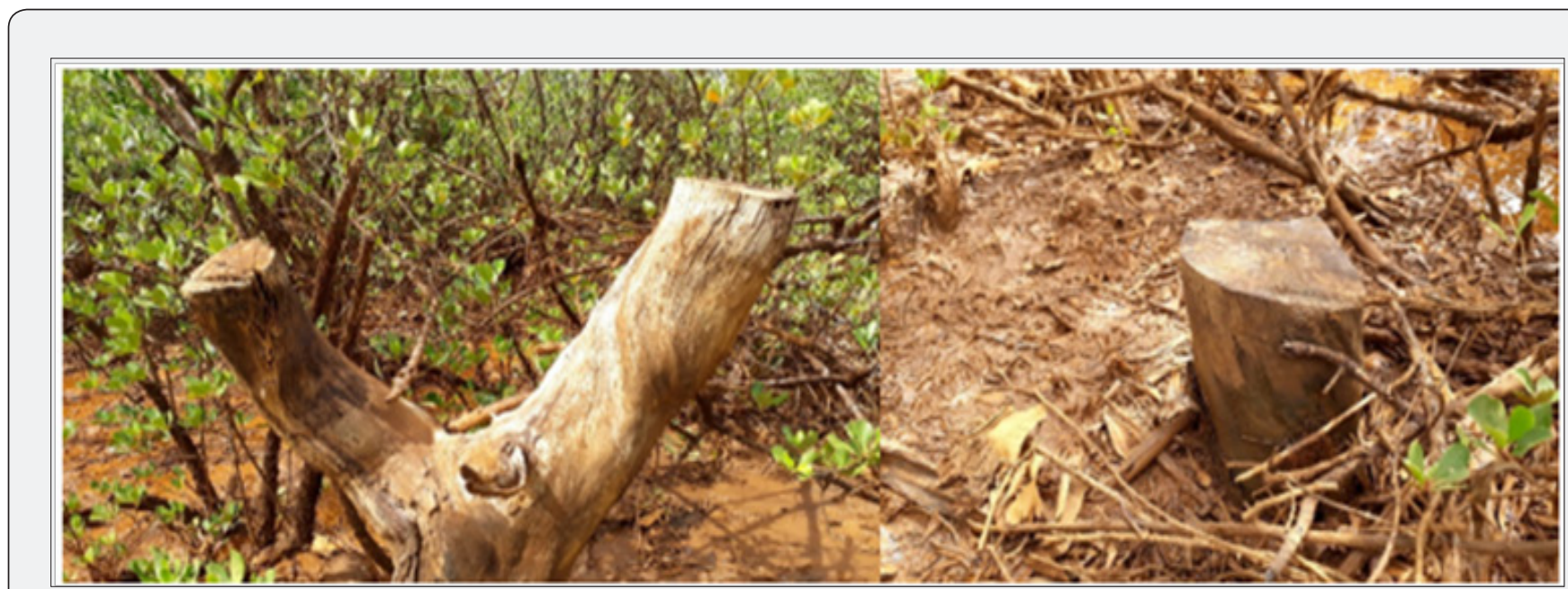

Figure 8: Illegal cutting of mangrove trees used as fire-wood (Uling) by locals.

\section{Vegetation analysis}

The mangroves community structure was evaluated by using the values of population density, relative density, frequency, relative frequency, dominance and relative dominance. The summations of these values were added to attain species importance value (SIV) in the entire sampling area. The species Lumnitzera littorea was noted of having the highest population density indicating that this species has the highest count per unit area, followed by Acrostichum speciosum and Lumnitzera racemosa (Figure 9). For relative frequency, Lumnitzera littorea and Bruguiera sexangula had the highest value followed by Lumnitzera racemosa (Figure 10). Dominance still dominated by Lumnitzera littorea (Figure 11) including the species importance value as shown in Figure 12.

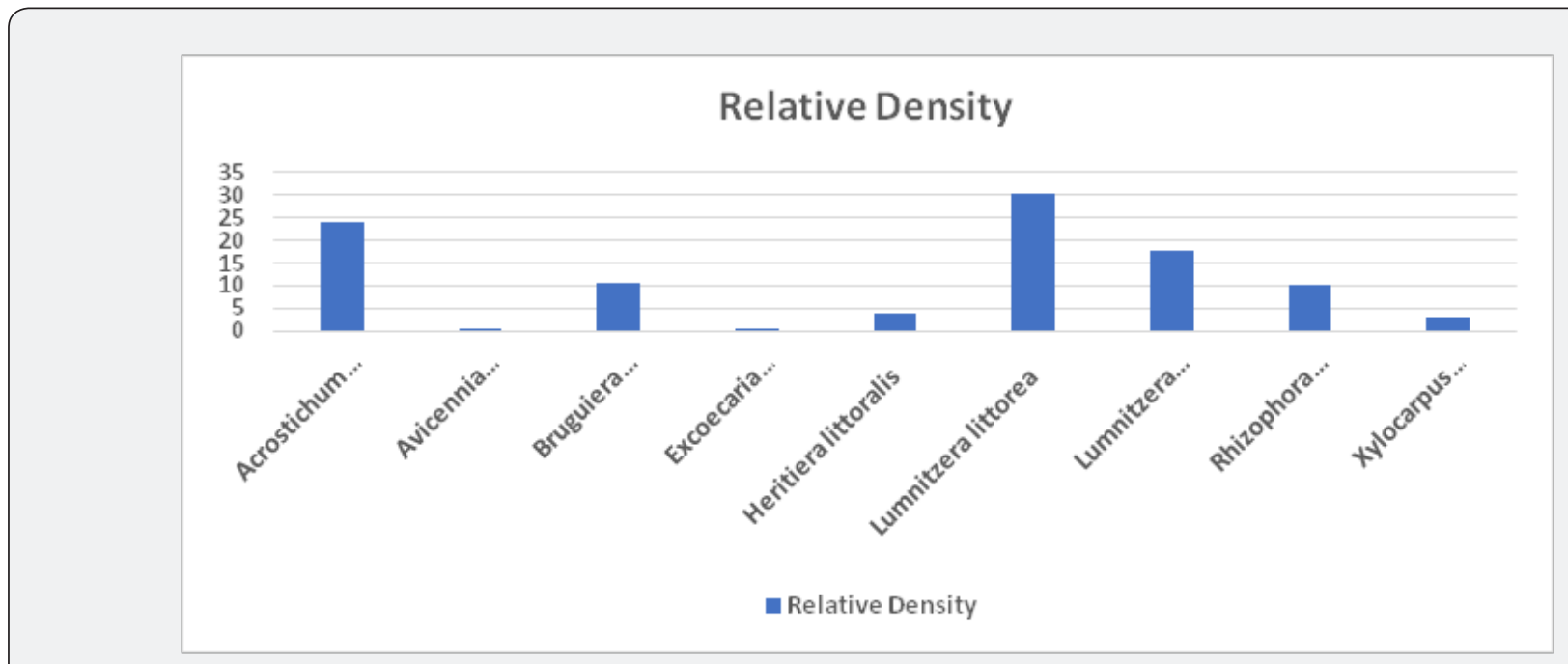

Figure 9: Relative population density of mangrove species within the areas of Cagdianao, Claver, Surigao del Norte. 


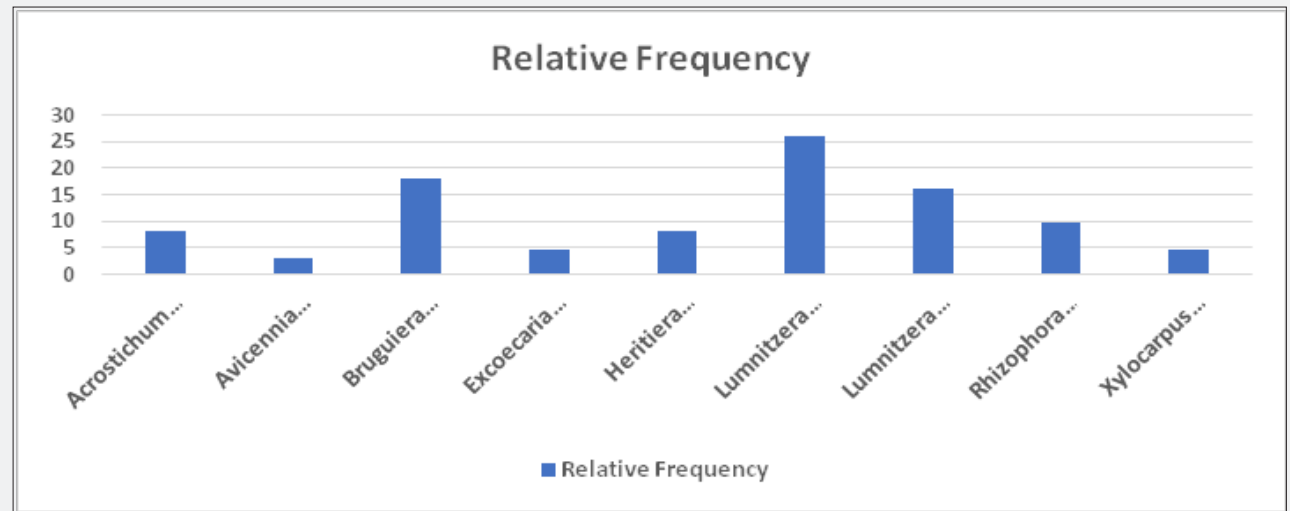

Figure 10: Relative frequency of mangrove species within the areas of Cagdianao, Claver, Surigao del Norte.

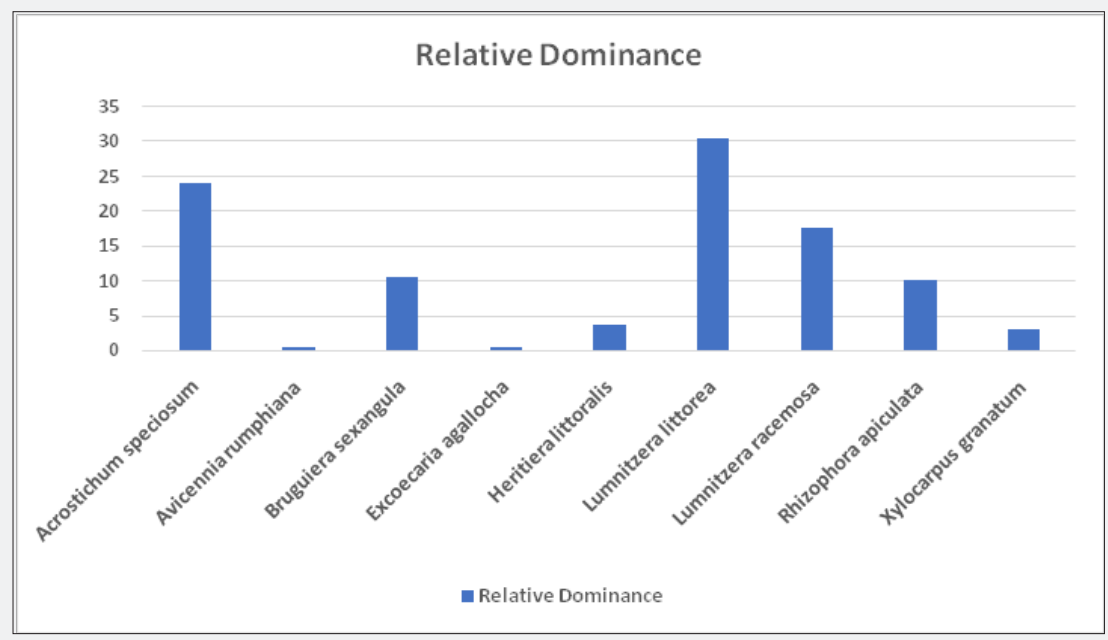

Figure 11: Relative frequency of mangrove species within the areas of Cagdianao, Claver, Surigao del Norte..

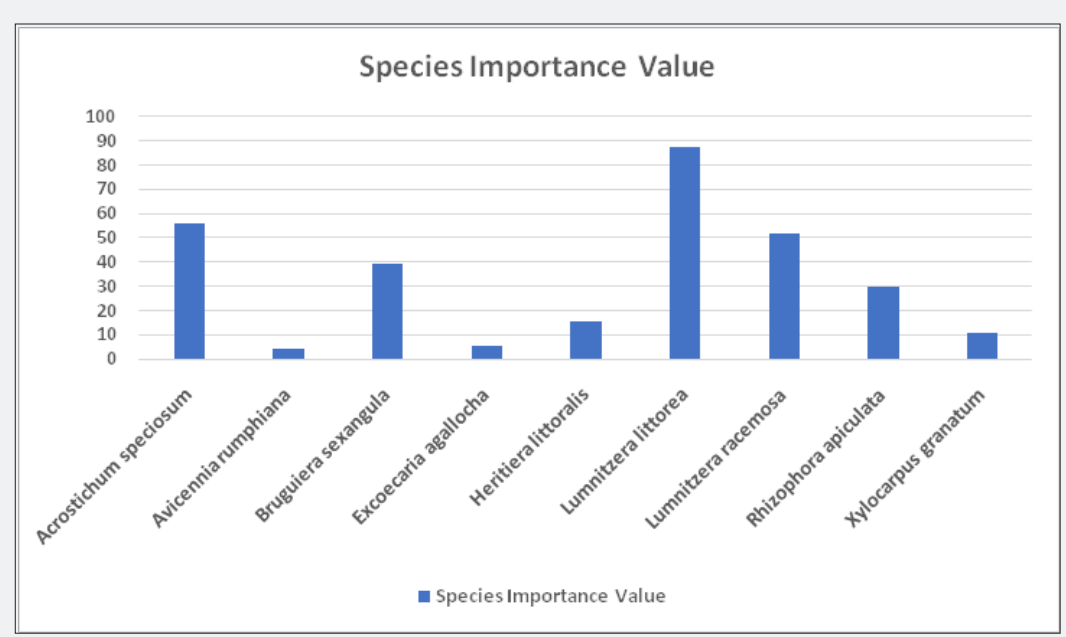

Figure 12: Relative Importance Value of mangrove species within the areas of Cagdianao, Claver, Surigao del Norte. 


\section{List of mangrove species}

Nine (9) species were found and recorded within the sampling station in Cagnianao, Claver Surigao Del Norte mangrove areas excluding the planted (through rehabilitation program) seedlings
(Figure 13). Other mangrove species are planted by the Mine Environment Division through its rehabilitation program. These species are Nypa fruticans (Nipa) and Rhizophora mucronata (Bakhaw Bae).

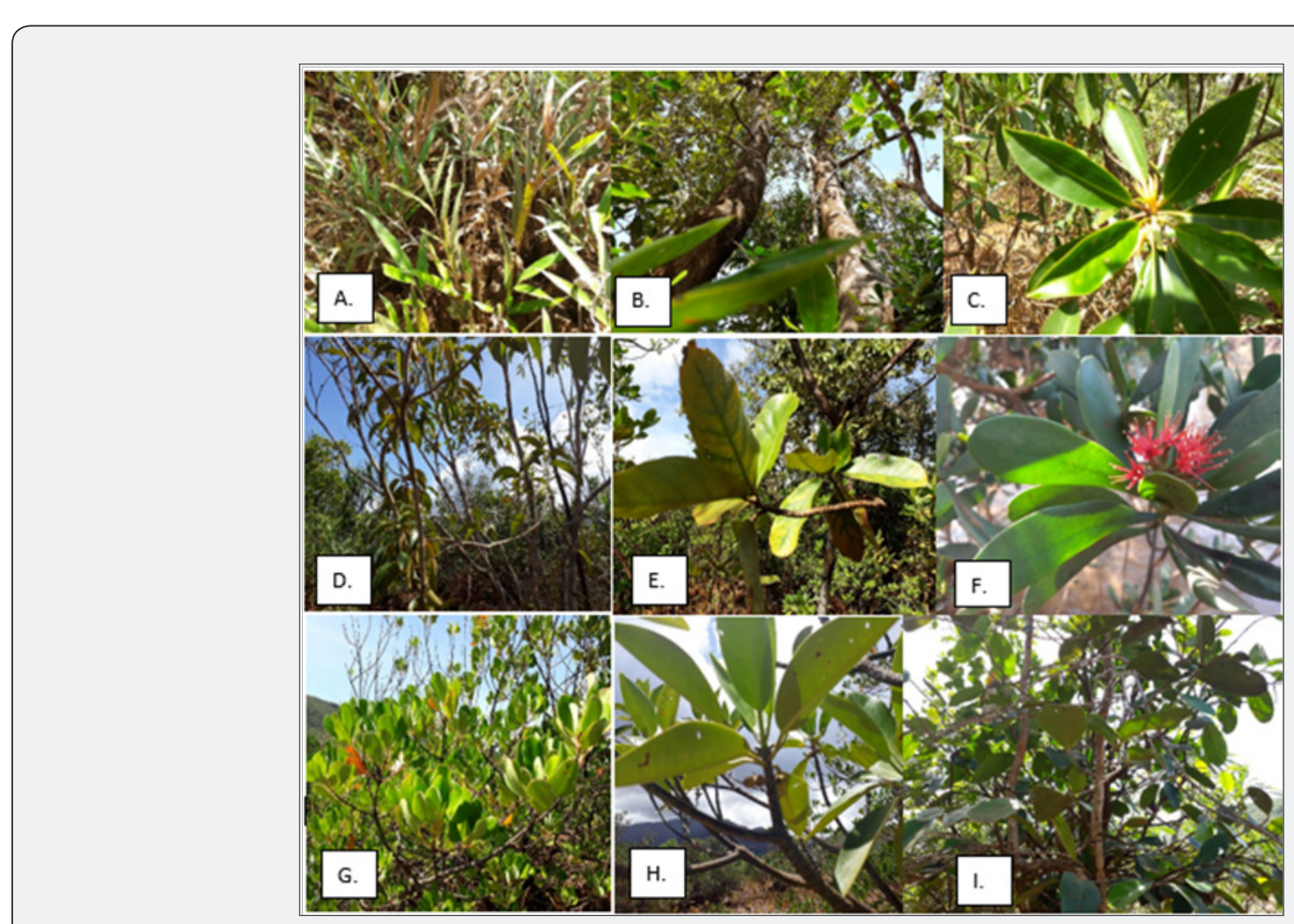

Figure 13: Pictures of all mangroves species found within the coastal area of Brgy. Cagdianao, Claver, Surigao del Norte, Philippines. (A. Acrostichum speciosum, B. Avicennia rumphiana, C. Bruguiera sexangula, D. Excoecaria agallocha, E. Heritiera littoralis, F. Lumnitzera littorea, G. Lumnitzera racemose, H. Rhizophora apiculate and I. Xylocarpus granatum).

\section{Conclusion}

Based on the results and findings of the study, it was concluded that the mangrove areas of Brgy. Cagdianao, Claver, Surigao del Norte falls under very low biodiversity. The area has a total number of nine mangrove species in seven families. Among the 9 mangrove species, Lumnitzera littorea and Acrostichum speciosum dominated the area in terms of abundance, frequency and individuals recorded. Habitat assessment showed that regeneration ( 3 individuals) per $\mathrm{m}^{2}$ was considered excellent and moderate category for average height of mangroves. This means that the area experienced very low disturbances from anthropogenic activity. The total average canopy cover (cc) within the mangrove area of Cagdianao had a total value of 43.88 almost $43 \%$ in which it is interpreted as Moderately Closed Canopy (MC) per square meter still intact mangrove density. Mangrove vegetation analysis showed that Lumnitzera littorea had the highest value in terms of relative frequency, relative density, relative dominance, and species importance value followed by Acrostichum speciosum and Lumnitzera racemosa repectively. Some important other species of plants such as $X$. verdugonianus, $P$. utilis and $Q$. indica were identified and thrived together with true mangrove species.

\section{Recommendation}

With the presented result, mangroves play very important role in maintaining ecological balance both living organism and nonliving. Conservation effort must be considered knowing that the area has a number of threatened species and experience anthropogenic damages. With that, the area obtained a very low biodiversity of mangroves. For Future studies, it is highly recommended to have a comprehensive assessment on soil and water analysis along mangroves area of Cagdianao, Claver, Surigao del Norte. 


\section{Acknowledgment}

Our sincere gratitude to the Municipality of Claver through Barangay Cagdianao, Officials and Platinum Group of Metal Corporation (PGMC) for the support of this research as well as in the researcher affiliated institution, the Caraga State University, and Pigdaulan National High School, Division of Butuan City.

\section{References}

1. Nagelkerken (2009) Ecological Connectivity among Tropical Coastal Ecosystems, C_ Springer Science + Business Media B.V.

2. Lee SY, Primavera JH, Guebas FD, MvKee K, Bosire JO, et al. (2014) Ecological role and services of tropical mangrove ecosystems: a reassessment. Global Ecol Biogeogr 23(7): 726-743.

3. Kathiresan K, Bingham BL (2001) Biology of mangroves and mangrove ecosystems. Advances in Marine Biology 40: 81-251.

4. Giri C, Ochieng E, Loveland T, Zhu Z, Singh A, et al. (2011) Status and distribution of mangrove forests of the world using earth observation satellite data. Global Ecology and Biogeography (20): 154-159.

5. Yoshiro M, Michimasa M, Motohiko K, Phan NH (1997) Mangroves as a coastal protection from waves in the Tong King delta, Vietnam. Mangroves and Salt Marshes 1(2): 127-135.

6. Alongi DM (2008) Mangrove Forests: Resilience, protection from tsunamis, and responses to global climate change. Estuar Coast Shelf Science 76(1): 1-13.

7. Alongi DM (2014) Carbon Cycling and Storage in Mangrove Forests. Annu Rev Mar Sci 6: 195-219.

8. Garcia K, Gevana D, Malabrigo P (2013) Mangrove Ecosystems of Asia: Status, Challenges and Management Strategies. In: Ibrahim FH, Latiff A, Hakeem KR, Ozturk M (Eds.), Chapter: Philippines' Mangrove Ecosystem: Status, Threats, and Conservation. Project: Mangrove Blue Carbon Project, Publisher: Springer Science + Business Media New York, USA.
9. Long JB, Chandra G (2011) Mapping the Philippines' Mangrove Forests Using Landsat Imagery. Sensors 11(3): 2972-2981.

10. Primavera JH, Sadaba RB, Lebata MJHL, Altamirano JP (2004) Handbook of mangroves in the Philippines - Panay. SEAFDEC Aquaculture Department, Tigbauan, Iloilo, Philippines, pp. 1-106.

11. Goloran AB, Laurence C, Glenn B, Tricia MA (2020) Species Composition, Diversity and Habitat Assessment of Mangroves in the Selected Area along Butuan Bay, Agusan Del Norte, Philippines. Open Access Library Journal 7: e6249.

12. Cañizares LP, Seronay RA (2016) Diversity and species composition of mangroves in Barangay Imelda, Dinagat Island, Philippines. AACL Bioflux 9(3): 518-526.

13. English S, Wilkinson C, Baker V (1997) Survey manual for tropical marine resources. Australian Institute of Marine Science, Townsville Mail Centre, Australia, pp. 119-196.

14. Deguit ET, Smith RP, Jatulan WP, White AT (2004) Participatory coastal resource assessment training guide. Cebu City: Coastal Resource Management Project of the Department of Environment and Natural Resources, Philippines.

15. Øyvind H, Harper DAT, Ryan PD (2001) Past: Paleontological Statistics Software Package for Education and Data Analysis. Palaeontologia Electronica 4(1): 9.

16. DENR (2017) Administrative Order No. 11, List of Threatened Plants of the Philippines. Department of Environment and Natural Resources, Philippines.

17. Demetillo MT, Lador P, Seronay RA (2015) Floral Assessment in Lake Mainit Watershed, Caraga Region, Mindanao Philippines. Annals of Studies in Science and Humanities 1(2): 12.

18. Su G, Huang Y, Tan F, Ni X, Tang T, et al. (2007) Conservation genetics of Lumnitzera littorea (Combretaceae), an endangered mangrove from the Indo-West Pacific. Mar Biol 150: 321-328.

19. Tomlinson PB (1986) The Botany of Mangroves. Cambridge University Press, New York, USA, p. 413.

Your next submission with Juniper Publishers will reach you the below assets

- Quality Editorial service

- Swift Peer Review

- Reprints availability

- E-prints Service

- Manuscript Podcast for convenient understanding

- Global attainment for your research

- Manuscript accessibility in different formats

( Pdf, E-pub, Full Text, Audio)

- Unceasing customer service

Track the below URL for one-step submission https://juniperpublishers.com/online-submission.php 